\title{
A utilização de imagens e textos como estratégias de banalização e modos de naturalização das desigualdades em notícias sobre a pobreza dentro dos jornais
}

\author{
The use of images and texts as trivializing strategies and ways of \\ naturalization of news inequalities on poverty in the newspapers
}

\author{
Bruna Clézia Madeira Neri \\ Francisca Denise Silva do Nascimento
}

Resumo: Nossa discussão versa sobre as estratégias de naturalização e modos de banalização que são construídas dentro das notícias de um jornal. Os fatos que o jornal narra acabam por carregar ideologias que reificam e banalizam determinadas situações e pessoas, alimentando estereótipos e preconceitos. Este artigo expõe categorias que servirão como molde para o recorte do problema, dentre elas: A Pobreza, a Exclusão e a Desigualdade. Buscando entender melhor o papel da mídia na elaboração das notícias, faremos um estudo das conceituações sobre Ideologia, tema de central importância para a compreensão das estratégias de banalização e naturalização aqui discutidas e utilizamos como base para esta apresentação a metodologia da Análise Crítica do Discurso (ACD). Na análise propriamente dita, trabalhamos com notícias veiculadas pelo jornal cearense $\mathrm{O}$ Diário do Nordeste (DN), fonte de dados que nos permite apontar e debater as categorias propostas no início de nossa explanação.

Palavras-chave: Ideologia; Desigualdade; Mídia; Análise Crítica do Discurso; Jornal.

\begin{abstract}
Our discussion deals with the naturalization strategies and trivialization modes that are built into the news a newspaper. We take as a starting point the hypothesis that social inequalities are treated differently in the constitution of a news story. The facts that the newspaper recounts end up carrying ideologies that reify and trivialize certain situations and people, feeding stereotypes and prejudices. This exposes TCC categories
\end{abstract}

Latitude, Vol. 10, no 1, pp. 50-82, 2016

DOI: https://doi.org/10.28998/2179-5428.20160103 


\section{Bruna Clézia Madeira Neri \\ Francisca Denise Silva do Nascimento}

that will serve as a template for the problem of clipping, among them: Poverty, Inequality and Exclusion. Seeking to better understand the media's role in preparing the news, we make a study of the concepts of ideology, central topic of importance for understanding the banalization strategies and naturalization discussed here. We used as the basis for this presentation methodology of Critical Discourse Analysis (CDA), theoretical framework that allows us to thoroughly investigate the news chosen to be discussed. To to list objectively our methodological framework will use the Critical Tradition Linguistics, ACD branch that has strong links with studies involving the media, by treating discourses as social constructs within structured contexts. In actual analysis, we work with news published by Ceará newspaper O Diário do Nordeste (DN), data source that allows us to point out and discuss the categories proposed in the beginning of our explanation.

Keywords: Ideology, Inequality, Media, Critical Discourse Analysis, Journal.

\section{País rico é país sem pobreza, mas o brasil é pobre de que?}

A Pobreza, nos moldes que a conhecemos, seja nas ruas ou nos noticiários de TV, nos hospitais lotados, presídios, manicômios, albergues ou favelas, está sempre nos comunicando algo que não deixaremos passar de forma despercebida: vivemos num país desigual. Essa é a premissa básica para compreendermos a importância das categorizações acima registradas. O slogan antigo do nosso governo era "País Rico é País sem Pobreza" 1, mas, o que caracteriza essa pobreza? É miséria? De que? De comida? De moradia? De saneamento? A onda assistencialista que invadiu o governo brasileiro nos últimos anos tem trazido essa ambiguidade, que só fica clara após um olhar mais atento para as sutilezas que ele nos repassa: é possível acabar com a pobreza em nosso país à medida que gratificamos por mês famílias de baixa renda com uma quantia de cinquenta reais caso elas se comprometam a garantir $100 \%$ de presença de seus filhos na escola?

${ }^{1}$ Disponível em http://www.brasil.gov.br/noticias/arquivos/2011/02/10/governo-lanca-novalogomarca-com-slogan-pais-rico-e-pais-sem-pobreza 20/06/2013 acesso em 15 maio. 2013. 
A utilização de imagens e textos como estratégias de banalização e modos de naturalização das desigualdades em notícias sobre a pobreza dentro dos jornais

Nathalie Beghin (2009, p.592) ao pontuar algumas notas sobre a pobreza e a desigualdade, defende que "no Brasil [a pobreza] tem cor e endereço: é negra, urbana e está concentrada no Nordeste". Ora, se a pobreza em nosso país é negra e nordestina, então a nata opulenta que detém o poder é branca, e é provável que se concentre principalmente (mas não totalmente) no Sul e Sudeste, regiões onde há maior desenvolvimento e mais geração de renda. ${ }^{2}$ Mariangela Belfiore Wanderley (2010, p.23) nos diz que a pobreza contemporânea:

Tem sido percebida como um fenômeno multidimensional atingindo tanto os clássicos pobres (indigentes, subnutridos, analfabetos...) quanto outros segmentos da população pauperizados pela precária inserção no mercado de trabalho. Não é resultante apenas da ausência de renda; incluem-se aí outros fatores como o precário acesso aos serviços públicos e, especialmente, a ausência de poder. Nesta direção, o novo conceito de pobreza se associa ao de exclusão, vinculando-se às desigualdades existentes e especialmente à privação de poder de ação e representação e, nesse (grifo da autora) sentido, exclusão social tem que ser pensada também a partir da questão da democracia.

Uma categorização dos conceitos, entretanto, não implica a anulação do fato que há uma relação que permeiam os seus sentidos. Para isso, precisamos ter muito clara a lógica de que categorizar é valorar de acordo com determinados aspectos que surgem e se repetem. Podemos categorizar de forma rude os pobres como aqueles que não têm dinheiro e ricos como aqueles que têm dinheiro. Entretanto, não podemos inferir com isso que uma pessoa é pobre porque é o destino dela viver assim. Quando se tomam atitudes assim as pessoas passam a ser dominadas (GUARESCHI \& BIZ, 2005), o cultural vira natural (THOMPSON, 2011) e "vai ser sempre assim porque é assim que sempre foi". Se há poucos com tanto e muitos

${ }^{2}$ Não se quer dizer com isso que não haja pobreza no Sul e Sudeste. O Brasil carrega esse problema em todas as suas regiões. 


\section{Bruna Clézia Madeira Neri \\ Francisca Denise Silva do Nascimento}

com tão pouco, deve haver algo errado. É a partir daqui que embutimos na análise um novo conceito: a relação.

Guareschi (1992a), no artigo "A Categoria Excluído" põe em discussão essa questão. Para ele, ao pensarmos Pobreza como uma relação, precisamos mudar o termo utilizado, pois não existe alguém enriquecido sem alguém que o enriqueceu, o mesmo vale para alguém pobre. A necessidade do outro $^{3}$ constitui uma relação. Em sua obra, ele faz a seguinte conceituação:

Relação, como a definimos, é a ordenação intrínseca de um ser em direção a outro (a "ordo ad liquid" da boa filosofia). Assumimos também o ser humano como "relação", isto é, como um ser que se constrói e se constitui a partir dos milhões de relações que ele estabelece com todos os seres existentes. (GUARESCHI, 2010, p.144)

O excluído categorizado como pobre não foi excluído por natureza, e sim por outros homens. Ele não existe por si mesmo, mas nasce como fruto das relações de desigualdade dentro de uma sociedade. Se há excluídos, é porque existe um sistema que inclui e seleciona categórica e hierarquicamente $\mathrm{o}$ que pode ou não entrar no rol "cidadão" ${ }^{4 "}$. Vagabundos ${ }^{5}$ mendigos, prostitutas, meninos de rua, analfabetos, favelados em geral, todos são excluídos de um sistema perverso. Podemos chama-los de empobrecidos, filhos da falta, desde a comida até a dignidade.

\footnotetext{
${ }^{3} \mathrm{O}$ desconhecimento do 'outro' que é fruto de uma segmentação social dissipa a criação e perpetuação de estereótipos envolvendo a pobreza e dá cabimento para que se gere um "não reconhecimento" ou um sentimento de semelhança. $O$ "não reconhecimento" é visto como uma forma de identificação precária e precipitada, tornando-se um dos pilares que sustenta o que hoje significamos como "Desigualdade".

${ }^{5}$ Robert Castel (2010, p.119-120) trabalha com o conceito de "inútil para o mundo" quando se refere aos vagabundos. Para ele, há dois critérios constitutivos da categoria de vagabundo, que se tornam explícitos: o primeiro é a ausência de trabalho, ou seja, a ociosidade ligada à falta de recursos e o fato de ser "sem fé nem lei", isto é, sem pertencimento comunitário. O vagabundo é uma mancha, “completamente invisível porque totalmente desterritorializado, e sobre ele vai abater-se um arsenal sempre renovado de medidas cruéis".
} 
A utilização de imagens e textos como estratégias de banalização e modos de naturalização das desigualdades em notícias sobre a pobreza dentro dos jornais

É também interessante dar-se conta que a exclusão econômica é, na maioria das vezes, senão a causa, ao menos a condição para a exclusão política, religiosa, cultural e social. Sem defendermos um determinismo econômico, percebemos, contudo, que à medida que as pessoas são privadas das necessidades básicas de sobrevivência, como alimentação, saúde, moradia, etc. nessa medida são também marginalizados dos outros benefícios sociais. (GUARESCHI, 1992a, p.8)

A situação de empobrecimento aliada ao sentimento de Exclusão resulta no que apontamos como Desigualdade. Karl Marx nos diz que "deve haver algo de podre no cerne de um sistema que aumenta sua riqueza sem diminuir sua miséria." (GABRIEL, 2013, p.21). Semelhante pensamento tem Duncan Green (2009, p.5), que faz uma comparação quando aponta: "Há algo de profundamente injusto em um sistema que permite que 800 milhões de pessoas passem fome enquanto uma epidemia de obesidade aflige milhões em países ricos".

No decorrer de nossa investigação, sempre que falarmos de pobreza, estaremos partindo do referencial de Guareschi. Sua proposta é que, a pobreza inserida num rótulo, mais do que uma conceituação ou categorização terminológica, abrange em seu âmago uma relação (o empobrecimento), e é só através desta relação que se faz possível o objetivo de explicar dialeticamente porque existem empobrecidos, e não pobres, uma vez que tal condição não é um enquadramento dos sujeitos em algo e sim a definição de uma situação pela qual eles passam diariamente, cujas bases constitutivas não são naturais e sim culturais.

\section{Mídia e ideologia}

Aqui analisaremos uma nova perspectiva que se propõe a entender o que é ideologia, a partir do olhar de Thompson (2011). O autor combate a ideia de neutralização da ideologia e formula uma concepção crítica com um enfoque eficaz para a análise concreta dos fenômenos sócio históricos. Ele se utiliza do conceito de 'formas simbólicas' para explicar as relações de poder e defende que "estudar a ideologia é estudar as maneiras como o 


\section{Bruna Clézia Madeira Neri \\ Francisca Denise Silva do Nascimento}

sentido serve para estabelecer e sustentar relações de dominação" (p.76). As formas simbólicas podem ser entendidas como um vasto conjunto de ações, imagens, falas, sons e textos que nós produzimos e que são reconhecidos por outros sujeitos como conteúdo significativo. São essas formas simbólicas que mobilizam o sentido, estabelecendo assim a dominação enquanto uma relação. Os sentidos são as formas simbólicas inseridas em contextos sociais e circulando no mundo social. $\mathrm{O}$ autor vai questionar sobre quais as maneiras em que o sentido pode servir para estabelecer e sustentar as relações de dominação, nos dando o seguinte mote: Há certos modos e estratégias de operação da ideologia que nos indicam como eles podem estar ligados, em circunstâncias particulares, com construções simbólicas.

Thompson (2012, p.80-89) vai citar um conjunto de categorias que ele caracteriza como modos de operação da ideologia. Existe o uso da ideologia através de "modos" (representando uma forma mais geral de operação da ideologia) e de "estratégias" (forma particular de operação da ideologia, caracterizando a maneira como os 'modos' funcionam). Não cabe aqui explanar o que significa cada uma dessas categorias, mas vale salientar que elas são extremamente minuciosas para descrever com propriedade relações de poder e dominação. Para este trabalho, escolhemos a priori uma destas categorias, que julgo importante para atingir o objetivo proposto de estudar notícias, é ela: a Reificação.

A Reificação é um modo de operação da Ideologia no qual as relações de dominação "podem ser estabelecidas e sustentadas pela retratação de uma situação transitória, histórica, como se essa situação fosse permanente, natural, atemporal". (THOMPSON, 2011, p.87).Este modo de operação ideológica tem duas estratégias de funcionamento: a Eternalização e a Naturalização, esta última, nossa escolhida para, de fato, alicerçar a análise das notícias.

$\mathrm{Na}$ Eternalização, os fenômenos sócio-históricos têm seu caráter 'histórico' esvaziado ao serem apresentados como permanentes e imutáveis (2011, p.88). Podemos imaginar costumes, tradições e instituições que sempre se remetem ao passado de tal forma que se perde todo o questionamento sobre as finalidades e sentidos de suas ações. As práticas tornam-se engessadas e é quase impossível quebrar essa rigidez. A segunda estratégia é a Naturalização. Investigaremos as notícias com a premissa de que é possível encontrar discursos que naturalizam as desigualdades. 
A utilização de imagens e textos como estratégias de banalização e modos de naturalização das desigualdades em notícias sobre a pobreza dentro dos jornais

Guareschi não tem um conceito fechado do que seja Ideologia, para ele, dependendo do tipo de relação estabelecida em determinado contexto, os eixos podem se modificar. Como a proposta é analisar a mídia transpassada pela ideologia, podemos falar, por exemplo, de relações de dominação (THOMPSON, 2012) dentro da mídia que sempre mudam. Nesse caso, falaria então de uma ideologia negativa e dinâmica, e daí por diante.

Guareschi vai ter uma forte influência de Thompson em sua teoria, e aqui podemos fazer uma conexão muito interessante entre ambos, que norteará os próximos pontos que irei discutir: Se ideologia é um termo multifacetado e complexo, tomado por diversas acepções, ele deve ser visto sob uma perspectiva crítica, como aponta Guareschi; em seu sentido (eixo) negativo crítico, proposto por esse autor, a ideologia é um conjunto de ideias que servem para iludir, distorcer e maquiar uma realidade dada. Se dispusermos da ideologia no eixo da prática, ou seja, como algo dinâmico, teremos então uma ideologia que está sempre em movimento, apresentando coisas novas (que não são necessariamente boas) e transformando a realidade. A conexão reside da seguinte forma: ideologia dentro de uma visão negativa e dinâmica é justamente aquilo que Thompson vai defender em seus escritos, uma ideologia que, através do uso de formas simbólicas, cria ou mantém relações de dominação. Para Guareschi

Mais do que identificar cosmovisões gerais de pessoas ou grupos, o que na verdade cremos ser importante e necessário é revelar como as pessoas sofrem e são prejudicadas, na sua vida cotidiana, devido a relações que são estabelecidas de maneira desigual e injusta. (2012, p.101)

Anteriormente apontamos a Naturalização descrita por Thompson como nossa escolha entre os modos de operação da ideologia. O segundo modo nos é agora apresentado por Guareschi. Este novo tópico é a banalização (ou "diluição" da realidade) que tem como uma de suas estratégias o fait-divers:

A própria definição etimológica de fait-divers significa "um fato diverso", isto é, que desvia do assunto, que reorienta para outra direção, podendo 
até mesmo distorcer. A estratégia do fait-divers é uma forma de garantir a transferência da responsabilidade para uma noção de destino, de fatalidade, que não tem compromisso com a descrição fiel dos fatos. Não sugere nenhuma reflexão aprofundada, pois notabiliza-se pela superficialidade. (GUARESCHI, 2000, p.323)

A banalização também abarca outras estratégias como a ironia e o entretenimento. A ironia é utilizada para transformar uma informação relevante à sociedade em algo sem importância, cômico. A cristalização das situações as torna ridículas, geralmente pela comparação feita entre o que é e o que poderia ser. "É através do cômico, do divertimento e da banalização do real que se desvia a atenção de problemas fundamentais tornando-se assim o cômico uma nova estratégia para criar e reproduzir ideologias". (GUARESCHI, 2000, p.304). A ironia também faz com que formas esquemáticas possam ser utilizadas com objetivo crítico ou reforçador da banalização do elemento em questão. Essa seria uma forma de degradar a realidade que é, ou deveria ser, objeto de admiração comum (GUARESCHI, 2000 apud, MONGELLI, 1983).

Antes de começarmos a discussão, precisamos esclarecer exatamente o que estaremos chamando de mídia: ela constitui os meios técnicos e organizacionais complexos que incluem tipicamente televisão, cinema, jornais, livros, revistas e internet (JOHNSON, 1997, p.45).

Não se pode discutir o papel da mídia dentro de uma sociedade sem entender que ela carrega consigo uma série de valorações positivas ou negativas, geralmente dinâmicas, e que há um modus operandi por trás de cada informação veiculada, cujos propósitos atendem a interesses muito específicos, que geralmente não são os das pessoas que recebem essa mesma informação. Ou seja, a mídia carrega consigo ideologias.

Para Thompson (2012), a mídia é compreendida como um poder que detém a capacidade de moldar os meios de comunicação e informação. Este poder pode ser visto como uma das ramificações que o autor discorre sobre o que ele acredita constituir as formas de poder: o poder econômico, que possibilita trocas financeiras e de materiais; o poder político, que institui a autoridade; o poder coercitivo representado pela força física e armada. Por último, o poder que nos interessa aqui, é o chamado poder 


\section{A utilização de imagens e textos como estratégias de banalização e modos de naturalização das desigualdades em notícias sobre a pobreza dentro dos jornais}

simbólico. Nesta categoria, estão inseridas as formações de meios de comunicação e informação, representados pelas instituições culturais como a Igreja, a escola, as universidades e a mídia. Esta divisão não é fixa e rígida, pois muitas instituições valem-se de recursos os mais diversos, fornecendo bases para diferentes formas de poder.

Quando investigamos as criações midiáticas precisamos considerar os estereótipos que fatalmente surgem em torno de determinados assuntos, como a desigualdade. Por estar munida de um grande poder simbólico e aliada, geralmente, a interesses estatais através da dialética da ambiguidade, citada anteriormente, a mídia trata de certos temas com um cuidado maior do que outros. Não é cabível para a imprensa que está aliada ao governo atual falar de seus erros e falhas, bem como não é vantajoso para o governo permitir que esta imprensa se torne aliada da oposição, pois se assim for, ela vai acabar apontando as fraquezas do governo, ao invés de exaltar seus méritos e logros. Há uma parceria onde ambos os lados lucram, mas o preço pago é alto: a informação chega até as pessoas de forma comprometida, ou, porque não dizer, afetada pelos interesses desses dois polos de poder. Não é bom para o crescimento da popularidade de um governo ter estampada nas capas de jornais sua fome e sua miséria, pois tudo o que é veiculado e comunicado para alguns "tem sempre um fundo de verdade". 6

De forma geral, a mídia está atenta às produções de verdade e realidade que seu poder simbólico cria e detém, e ao nos voltarmos para a discussão sobre ideologia que tratamos no início do capítulo, remetemonos a dois conceitos específicos apresentados por Guareschi e Thompson: para este, a ideologia é sempre crítica, jamais neutra, formada por

\footnotetext{
${ }^{6}$ Não vivemos numa ditadura, mas isso não quer dizer que o jornal seja livre para estar contra os interesses do poder. Podemos citar como exemplos o jornal O Pasquim, criado pelo cartunista Jaguar, nos anos de chumbo da ditadura pela qual o Brasil passou. O jornal foi perseguido e censurado por não estar de acordo com o que o governo fazia. (Fonte: http://caminhosdojornalismo.wordpress.com/producao-em-impresso-2/jornal-o-pasquim-2/, acesso em 30 jun de 2013.). Outro exemplo é o jornal $A$ Gazeta Renana, cujo um dos editores era Karl Marx. O jornal criticava o autoritarismo do governo prussiano, que era representado por uma monarquia e Marx, que acabou virando redator-chefe do jornal, defendia que o povo tomasse o poder e transformasse o governo em uma democracia. $\mathrm{O}$ governo obrigou Marx a abandonar o cargo e fechou o jornal (GABRIEL, 2013). O Pasquim e A Gazeta Renana já não existem mais bem como não existem mais jornais criticando diretamente sem mensagens subliminares as formas de governos atuais.
} 


\section{Bruna Clézia Madeira Neri \\ Francisca Denise Silva do Nascimento}

construções simbólicas que alimentam relações de dominação. Guareschi vai além e nos propõe pensarmos a ideologia de forma atravessada, entendendo que ela pode se guiar por critérios fundamentados numa plataforma sólida de ideias que visam uma transformação positiva, sempre mudando (eixo positivo e dinâmico) ou em um conjunto de princípios que norteiam relações que causam danos ao outro, oprimindo-o, dominando-o e desapoderando-o.

Aqui temos uma visão negativa e dinâmica da ideologia, e é através de tal posicionamento que iremos investigar o papel da mídia ao construir e veicular notícias envolvendo empobrecidos. Entendemos que devido ao seu caráter mantenedor de verdades e suas restrições no que diz respeito ao uso de princípios voltados para a construção de informações mais esclarecedoras e comprometidas com a transmissão fiel dos fatos, a mídia representa um veículo ideológico que legitima práticas de dominação através de seus discursos.

Hoje, o jornalismo impresso (que está também cada vez mais virtual) se mostra como um dos meios mais penetrantes, se não o mais influente, a se julgar pelo critério de poder baseado no número de receptores. Ao contrário do que muitos pensam, divagado pelo senso comum, as notícias veiculadas no jornal são mais lembradas do que aquelas que são apresentadas na televisão (VANDIJK, 2012 apud ROBINSON e LEVY, 1986) e são percebidas como qualitativamente superiores em termos de influência e persuasão (VANDIJK, 2012 apud JENSEN, 1986). A transmissão e disseminação de notícias é mais rápida através da televisão, mas é mais eficaz quando está atrelada ao papel, havendo menos dúvidas de sua confiabilidade e validação por parte do leitor. Este poder de credibilidade é usado de forma muito singular na construção de fatos e informações, já que a mídia jornalística decide as pautas a serem veiculadas (GUARESCHI \& BIZ, 2005). Mesmo com tentativas fadadas de se mostrar imparcial, ela é sempre valorativa, sendo uma atitude ingênua defender que a mídia tem pretensões de neutralidade e objetividade na busca pela verdade.

O grande engodo da questão é que a ideia de imparcialidade não é vista como algo real, e quando um jornal chega às mãos de um leitor, muitas vezes este pode estar pronto para tomar como indiscutível o fato exposto na manchete, entretanto, ele pode também questionar, não acreditar ou entender que essa notícia que está sendo veiculada é 
A utilização de imagens e textos como estratégias de banalização e modos de naturalização das desigualdades em notícias sobre a pobreza dentro dos jornais

tendenciosa. O segundo posicionamento é mais difícil de ser encontrado, pois avaliar criticamente o que a mídia nos coloca é muito arriscado, já que ela é uma fonte de poder que consensualmente carrega o estereótipo ${ }^{7}$ de sempre estar a favor da verdade. Dentro da comunicação "de massa" é mais comum encontrarmos o "sim, isso é verdade, aconteceu por que li no jornal". ${ }^{8}$

\section{O obscuro das notícias: o que elas não dizem ao dizer}

Ler o jornal constitui parte deste processo diverso, em que a notícia é produzida e veiculada, mas sempre sem saber ao certo até onde e quem vai atingir, ou a quais lugares vai realmente chegar. Como representa uma fonte de novidades, o jornal é preparado para ser o mais atrativo possível, nele os editores tentam estabelecer uma ordem lógica nas páginas, pois há materiais, espaços, fotos e anúncios diferentes que se ajustam dentro desse plano através das manchetes (SPINK et al, 2006).

Trabalhamos nas seções anteriores o fato de que a mídia não produz nada à toa, cada palavra de cada notícia está em seu devido lugar por questões circunstanciais que nem sempre são claras para o leitor. A compreensão do caráter ideológico de como as mensagens da mídia são repassadas pelos jornais impressos requer, portanto, uma investigação sobre o recebimento e incorporação das mesmas de forma reflexiva na vida das pessoas.

Ao escolhermos as notícias sobre os empobrecidos para constituir esta análise, atentaremos primeiro para um problema central: no plano discursivo da mídia os conteúdos ideológicos expostos obstaculizam de diversas maneiras a capacidade de reflexão dos sujeitos, e isso ocorre através do uso de estratégias que levam à naturalização e banalização dos repertórios interpretativos (SPINK et al, 2006; GUARESCHI \& BIZ, 2005; THOMPSON, 2012).

A identificação de noticias e imagens sobre a desigualdade social caracterizada pela banalização dos empobrecidos e a naturalização das

\footnotetext{
7 Todas as vezes que estivermos tratando de estereótipos, consideraremos que ele representa uma crença rígida, excessivamente simplificada, não raro exagerada, aplicada tanto a uma categoria inteira de indivíduos como a cada indivíduo na mesma. (JOHNSON, 1997, p.93)
} 


\section{Bruna Clézia Madeira Neri \\ Francisca Denise Silva do Nascimento}

desigualdades que circundam suas vidas em diferentes situações implica atentarmos para quais discursos estaremos nos voltando, já que dentro de um jornal de alcance estadual como é o escolhido desta explanação, há manchetes sobre crimes, violência, corrupção, trânsito, moda, saúde, etc.

Em minhas buscas, não encontrei dados específicos que utilizassem critérios quantitativos de venda e abrangência a respeito d'O Diário do Nordeste em comparação com o seu concorrente, O Povo, entretanto, no site www.netpapers.com, um banco de dados com informações de acesso a jornais de todo o mundo, há uma classificação dos quinze jornais cearenses registrados na ANJ (Associação de Jornais do Brasil) e nesta tabela, o jornal O Diário do Nordeste é o que possui um maior número de acesso através da plataforma, num total de 36.486 acessos até o presente momento ${ }^{9}$, seguido do jornal O Povo, com um total de 25.740 acessos. Com isso, temos uma proporção média de leitores que tem mais acesso ao Diário do Nordeste do que ao seu concorrente.

O Diário do Nordeste (DN) é um jornal impresso, com edições diárias, composto por quatro grandes sessões de notícias que acoplam cadernos com temas mais específicos. As sessões são: 'Notícias', 'Entretenimento', 'Esportes' e 'Especiais'. Dentro do bloco 'Notícias', teremos os cadernos: Opinião, Política, Cidade, Polícia, Regional, Nacional, Negócios, Empregos, Auto, Técnico, Tour, Última-Hora, Vida, Colunas e TV DN. Não irei especificar as outras sessões, pois a que vai nos interessar será apenas a primeira. Como podemos constatar, dentro da categoria 'Notícias' há um leque muito diversificado de informações, desde acontecimentos políticos até assuntos sobre tecnologia.

É com esta categoria que iremos investigar nosso problema. Faremos a escolha de uma subcategoria mais pertinente ao tema, aparecendo dentro da análise notícias vinculadas ao caderno 'Cidade'. Por ter edições novas todos os dias, os fatos mostrados no DN (utilizarei esta abreviatura sempre que me referir ao jornal $O$ Diário do Nordeste) são sempre curtas, não ultrapassando mais que meia lauda e algumas se restringem a dois ou três parágrafos, no máximo, sendo acompanhadas ou não de imagens. Estaremos mais atentos nesta análise às manchetes de notícias que perpassam ou tangenciam as categorias Pobreza, Exclusão e Desigualdade Social, como já foi explanado anteriormente.

9 Dado extraído do site http://www.netpapers.com/jornais-por-estado/brasil/ceara, acesso em 22 de maio de 2013, às $12 \mathrm{~h} 32 \mathrm{~min}$. 
A utilização de imagens e textos como estratégias de banalização e modos de naturalização das desigualdades em notícias sobre a pobreza dentro dos jornais

Averiguaremos com mais detalhamento a seguir cada uma das notícias escolhidas, analisando os discursos oriundos dos fatos narrados pelas reportagens. Por hora, vamos entender melhor o que discursos especificamente jornalísticos pretendem mostrar, dando enfoque às construções simbólicas e linguísticas que giram em torno da esfera de comunicação englobando a mídia impressa.

O jornal se constitui como um processo social que agrega leitor, escritor, gestor e anunciante, e nos oferece diversas possibilidades de construirmos um posicionamento a favor ou contra as notícias, estando no papel de compradores de um produto/ serviço ou no papel de expectadores em busca de informação sobre a sociedade (SPINK, 2006). Podemos dizer que o jornal faz parte do cotidiano de muitas pessoas, e quando ele banaliza e naturaliza situações que refletem uma situação de desigualdade, está também contribuindo para que esses valores sejam agregados ao dia-adia de muita gente. Tudo o que o jornal aponta, denuncia, desvenda também extrapola as folhas, e ao vir para o universo concreto da vida cotidiana, a desigualdade carrega os quesitos que ganhou dentro da notícia: se passou despercebida no jornal, é bem provável que também seja dada como invisível fora dele.

Fernando Luís González Rey (2006) aponta que a imprensa pode ser considerada uma via de expressão, recriação e produção de representações sociais que dominam uma sociedade, e com isso concebe um exemplo de manipulação simbólica facilitando a naturalização de certas explicações que criam 'tipos sociais' representantes da miséria atual. Os jogos de imagens e textos tendem a excluir reflexões mais profundas; as notícias são repassadas de forma curta e precisa, e não é necessário se ater a detalhes ou questionamentos, o que está no jornal é suficientemente satisfatório para compreender os acontecimentos cotidianos.

\section{O uso da análise crítica do discurso como estratégia metodológica na investigação de notícias}

Para dar conta do problema posto em análise neste trabalho, a metodologia escolhida como referencial na investigação das notícias expostas no DN foi a Análise Crítica do Discurso (ACD). A princípio, este conceito deriva da Análise do Discurso (AD), que é representada por um conjunto variado de enfoques no estudo de textos. A definição parece vaga, 


\section{Bruna Clézia Madeira Neri \\ Francisca Denise Silva do Nascimento}

mas cabe aqui explicar por hora que a $\mathrm{AD}$ tem inúmeras ramificações, e uma delas é a ACD. Entretanto, há caminhos em comum com todas as formas de AD, estas perspectivas, de acordo com Martin W. Bauer e George Gaskell (2012), irão partilhar de uma rejeição à noção realista de que a linguagem é apenas um meio neutro de reflexão e descrição do mundo. Elas também defenderão a importância central do discurso na construção da vida social. Apesar de haver pelo menos 57 variedades de AD, existem três tradições teóricas mais amplas que conseguem dar conta de abarcar todo o resto, são elas: a Tradição Linguística Crítica, a Análise da Conversação e o Olhar histórico dos Discursos. (BAUER \& GASKELL, 2012). Não há espaço aqui para nos determos em uma explicação minuciosa destes espectros teóricos, mas é importante descrever com um pouco mais de cuidado o que mais vai abranger a análise deste trabalho.

A Tradição Linguística Crítica tem como foco a compressão de que o sentido de um termo sempre provém de um sistema de oposições no qual ele se encontra inserido, e não de uma relação entre o significante e o significado. Esta nova percepção estabelece um desafio para as discussões sobre "palavra-objeto" da linguagem, vista como um mero processo de dar nome a algo. A Tradição Linguística Crítica é bem representada por estudos dentro do campo da mídia, especificamente em pesquisas que envolvem a imprensa, nas quais é enfatizada a maneira como formas linguísticas específicas podem ter efeitos sobre a dimensão de compreensão dos fenômenos (BAUER \& GASKELL, 2012).

Há autores como Dijk (2012) que considera o termo "Análise Crítica do Discurso" ultrapassado, e nos propõe uma nova nomenclatura chamada "Estudo Crítico do Discurso" (ECD). Para ele:

[...] os ECD não são, como frequentemente se presume - especialmente nas ciências sociais - um método de análise (grifo do autor) do discurso. Não existe esse tipo de método. Os ECD usam qualquer método que seja relevante para os objetivos de seus projetos de pesquisa e tais métodos são, em grande parte, aqueles utilizados em estudos de discurso geral. [...] pela mesma razão, também a análise do discurso (grifo do autor) em si não é um método; antes, constitui um domínio de práticas acadêmicas, 
A utilização de imagens e textos como estratégias de banalização e modos de naturalização das desigualdades em notícias sobre a pobreza dentro dos jornais

\author{
uma transdisciplinar distribuída por todas as \\ ciências humanas e sociais. (p.10-11)
}

Simplificando, podemos entender que o termo "discurso" é utilizado quando queremos nos referir a qualquer tipo de fala e texto, sejam eles formais ou informais. $O$ interesse aqui se deleita no texto em si, e não como uma ideia de que ele representa uma ponte para se chegar a uma dada face do real. O discurso é compreendido como uma prática social, uma vez que a linguagem também é uma prática. Nós a utilizamos para nos relacionar com o mundo. Pedimos perdão, damos bom dia, escrevemos livros, convencemos multidões, até, pois "como atores sociais, nós estamos continuamente nos orientando pelo contexto interpretativo (grifo da autora) em que nos encontramos e construímos nosso discurso para nos ajustarmos a esse contexto" (GILL,2012, p.248).

O contexto interpretativo se refere a tudo o que rodeia e perpassa o discurso, desde suas características mais sutis relacionadas à interação até os tipos de ações que estão sendo realizadas. Para se analisar criticamente um discurso é imprescindível atentar para o seu contexto interpretativo, pois sem ele o discurso fica deslocado da realidade na qual está inserido.

Outro fator importante é atentar para a circunstancialidade do discurso. Uma situação pode ser interpretada de diferentes modos, dependendo diretamente de quem estará entrando em contato com o discurso. Quando trabalhamos com mídia, isso é ainda mais comum de ser percebido. A mesma notícia pode ser interpretada de inúmeras maneiras por diversos pontos de vista. Tomemos como exemplo as atuais repercussões dos protestos que estão acontecendo em São Paulo (e no país inteiro) devido ao aumento na tarifa das passagens de ônibus aparecendo em uma manchete fictícia que diz "Polícia age de forma repressiva para conter as ondas de protestos e vandalismos na capital". Para um policial que está envolvido com a manifestação a manchete pode soar como verdadeira, afinal, ele está cumprindo o seu dever e se sente devidamente representado na notícia; ele também pode dizer que o termo utilizado foi mal colocado, não houve repressão e sim contenção de manifestantes. Já para um manifestante, a manchete pode parecer injusta e até mesmo falaciosa, pois ele pode alegar não estar cometendo nenhum ato de vandalismo, e sim lutando por seus direitos como cidadão. Dependendo das circunstâncias, o fato veiculado pode apresentar diferentes motes e o 
discurso se reconstrói de acordo com as novas interpretações que surgirão, e estas não aparecerão por acaso, ou por um mero "achismo":

Ações ou funções não devem ser pensadas em termos cognitivos, por exemplo, como relacionadas às intenções de alguém; muitas vezes elas podem ser globais ou ideológicas, e são melhor pensadas como práticas culturais, do que como confinadas na cabeça de alguém. Os analistas do discurso argumentam que todo discurso é circunstancial. (GILL, 2012, p.249).

Dentro da prática discursiva não existe nada "simples demais" ou sem importância. Na linguagem, tudo é relevante, desde uma posição das vírgulas que transforma o sentido de uma frase, até a frase como um todo, para quem e como ela se direciona, quais os seus possíveis sentidos.

\section{Histórias sobre os empobrecidos contadas pelo diário do Nordeste}

\section{NOTÍCIA 1 - A CRATERA DO BAIRRO BARROSO}

\section{Diário do Nordeste}

Fortaleza, Ceará - Quarta-feira, 3 de Outubro de 2012 - Caderno Cidade, p.4.

"DECON MULTA CAGECE POR FALTA DE ABASTECIMENTO"

Órgão alega que a companhia se omitiu de realizar ações para prevenir rompimento de adutora no Barroso.

A Companhia de Água e Esgoto do Ceará (Cagece) foi multada em R\$ 850,8 mil pelo Programa Estadual de Proteção e Defesa do Consumidor (Decon/CE). A multa é em virtude da falta de abastecimento do dia 9 de junho, quando mais de dez bairros sofreram com a falta de água.

Além disso, segundo o órgão fiscalizador, a empresa, mesmo tendo conhecimento do ato lesivo, não tomou imediatamente as providências necessárias para suavizar as consequências, ocasionando dano coletivo ou de caráter repetitivo aos consumidores atingidos. A respeito da multa, da qual a Cagece foi notificada no último dia 28, a companhia informou que apresentará sua defesa no prazo legal de dez dias. 
A utilização de imagens e textos como estratégias de banalização e modos de naturalização das desigualdades em notícias sobre a pobreza dentro dos jornais

A origem do problema foi o rompimento de uma tubulação com 1.200 mm de diâmetro, no bairro Barroso, e, como consequência, algumas regiões da Capital passaram mais de uma semana sem ter o abastecimento regularizado. $\mathrm{O}$ rompimento da adutora, além de gerar desabastecimento de água em pelo menos dez bairros das Regionais II, IV e VI, abriu uma cratera na rua. Algumas casas foram destruídas pela força da água e várias famílias tiveram que sair às pressas.

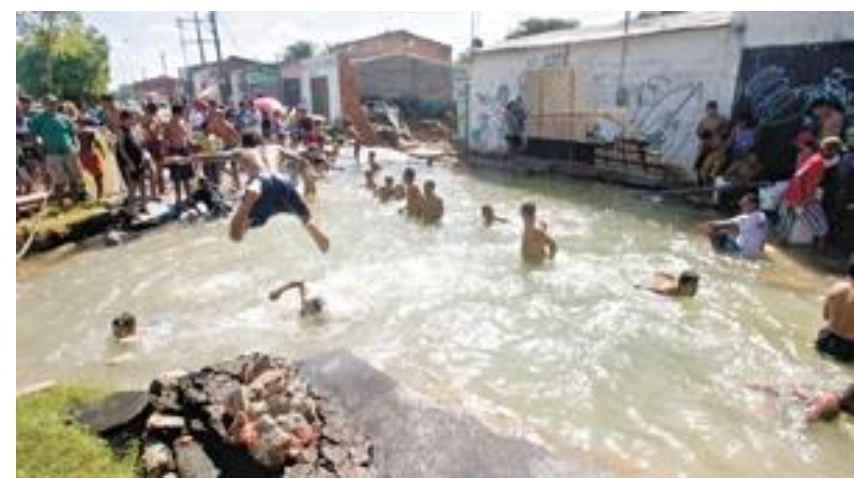

Imagem 1:

Mais de dez bairros de Fortaleza ficaram sem água após o rompimento de uma adutora no bairro Barroso, que abriu uma cratera na rua. Três residências foram completamente destruídas e dez parcialmente levadas pela água. Foto: Rodrigo Carvalho.

\section{Destruição}

Na época, o levantamento parcial da Defesa Civil de Fortaleza sobre o vazamento ocorrido na tubulação de água, no bairro Barroso, apontou que três casas foram totalmente destruídas e dez parcialmente levadas pela água.

Porém, não foi possível saber a quantidade de famílias prejudicadas e nem o número de bens perdidos, pois o órgão, na época, ainda estava fazendo apuração dos prejuízos no local.

As famílias que ficaram desabrigadas foram remanejadas para imóveis pelo Programa Aluguel Social, da Defesa Civil, e foram providenciadas três casas para outros que foram atingidos pelo rompimento.

Enquanto isso, a população do bairro João Paulo II, um dos mais atingidos com o vazamento da Cagece, se enfileirava para encher garrafões e potes como forma de armazenar água para as necessidades diárias. 
Nestes locais onde a pressão da água é menor, foi em média 15 dias para voltar o abastecimento.

\section{REPÓRTER: RODRIGO CARVALHO}

A temática da água é algo recorrente no $\mathrm{DN}$, talvez isso se dê pelo fato de que o Ceará é um Estado castigado pela seca e pelos baixos índices pluviométricos, sendo o bioma da caatinga uma paisagem predominante em grande parte do território que o compõe. Daí notícias que envolvem a água serem tão importantes, chegando a apresentar um cunho político, econômico e social dentro de seus discursos.

O que choca na notícia acima não é especificamente o texto, mas o conjunto texto-imagem. Se ela fosse composta apenas pelo texto talvez tivesse passado despercebida pelo nosso olhar, mas ao atentarmos para a cena de dezenas de pessoas tomando banho e até mesmo nadando dentro de uma cratera de água lamacenta no meio da rua, é difícil não retornarmos a uma das categorias centrais deste trabalho: a Desigualdade.

Após a discussão na seção 2 sobre as estratégias de banalização e o uso dofait-divers, podemos elencar como exemplo esta notícia que agora avaliamos. Ver as pessoas pulando dentro da cratera como se estivessem prestes a dar um mergulho em uma piscina seria cômico se não fosse essa marca de desigualdade que a imagem carrega já que é uma classe seleta que pode ter acesso a um lazer como a piscina e outra classe bem extensa que pode ter sua rua com uma "piscina natural" causada pelo descaso de alguma instituição. O que não podemos deixar passar é que essa tentativa sensacionalista de desviar a notícia do foco principal é uma estratégia muito utilizada dentro da mídia. Expõe-se o problema, as causas, mas tudo ocorre de forma muito breve e rasa, e para que a notícia cause impacto, seja chocando pelo riso ou pela incredulidade, se colocam imagens de efeito nas quais o leitor vai tirar suas conclusões não dos fatos narrados, mas sim das percepções através da cena.

A pobreza geralmente é tratada com escárnio pela mídia, quando não, é vista como trágica. A sensação que se quer passar é sempre a de que há uma rejeição velada com relação à "ralé", pois ela não possui educação, cultura e conhecimento dos próprios direitos e deveres. Por isso, ela deve ser sempre vista com um olhar que pré-julga despreparo, inaptidão e, porque não, um pouco de deboche. Quando o velho ditado retorna, como 
A utilização de imagens e textos como estratégias de banalização e modos de naturalização das desigualdades em notícias sobre a pobreza dentro dos jornais

nos lembra Ariano Suassuna, "pobre sempre ri da própria desgraça", encontramos a explicação para uma notícia como a que apresentamos acima ter mais sobreposição do que outras dentro do jornal: as pessoas são atraídas pelas mazelas do outro. Há um fascínio por ficar informado sobre as tragédias alheias, por mais que elas também façam parte da nossa vida.

O texto deixa claro que sua intenção é explicar quais providências serão tomadas para punir a CAGECE pelo descaso e qual a previsão de que "tudo volte ao normal". Não há precisão alguma de quantas famílias foram afetadas com o acontecido, nem as consequências para a saúde das mesmas a longo prazo- o que apontaria para a exclusão que acaba ficando invisível na matéria se lembrarmos do SUS apontando que Saúde é um direito de todos. Ter água encanada e limpa não é privilégio de todos no Ceará, infelizmente. Quem não pode contar com esse quase luxo, se vê obrigado a passar por situações limítrofes, como veremos mais a frente, na próxima notícia. No caso do Bairro Barroso, a notícia relata que "De acordo com o DECON/CE, a CAGECE pôs em risco a vida dos consumidores, tendo em vista que o abastecimento de água é um serviço essencial e a Companhia se omitiu de realizar ações preventivas na adutora, que já tinha mais de 30 anos de uso." O risco à vida dos moradores do bairro que se deu em virtude da falta de água, foi além, pois gerou o aparecimento de uma piscina gigante de água a menos de um metro da porta de suas casas, e isso não fica claro. Pessoas pulam e brincam alegremente dentro dela e não parece haver o mínimo cuidado com os riscos de contaminação e afogamento, sem falar nos problemas de saneamento decorrentes do escoamento dessa água, que carregará junto restos da rua afundada, entupindo algum esgoto, provavelmente, sem contar com o fato de há inúmeros malefícios para a saúde quando se entra em contato ou se está perto de água parada, a dengue é notoriamente uma das doenças mais prováveis de surgirem como consequência do descaso.

Quando o redator deu a notícia e fez uso de verbos como "omitir" ou expressões do tipo "tendo conhecimento do ato lesivo, não tomou imediatamente as providências necessárias" e "ocasionando dano coletivo ou de caráter repetitivo", ele enfatizou implicitamente que a CAGECE está ocupando o papel central de culpa pelo ocorrido. Nas nossas discussões sobre mídia e Ideologia, podemos relembrar o que apontam Guareschi\&Biz (2005): a mídia tem o poder de valorar os fatos. Na notícia exposta, concluise que a culpada por todo o transtorno foi apenas a CAGECE, não sendo 
citado nenhum outro órgão responsável por saneamento ou infraestrutura ligado ao poder municipal. Foi valorada à CAGECE um papel negativo no acontecido.

NOTÍCIA 2 - AS CARROÇADAS D'AGUA DE AQUIRAZ

\section{Diário do Nordeste \\ Fortaleza, Ceará - Quinta-feira, 18 de Outubro de 2012 - Caderno}

\section{Cidade, p.6.}

“POPULAÇÃO DA ZONA RURAL COMPRA ÁGUA PARA SOBREVIVER"

"A carroçada d'água", como é chamada pelos moradores, custa $R \$ 10$. São 400 litros, divididos em quatro tambores.

O abastecimento precário nas comunidades de Área Verde e Camará, localizadas no município de Aquiraz, é tão antigo que os moradores já perderam a esperança de que um dia o problema será solucionado. Os chafarizes estão lá, mas a água é salobra, imprópria para consumo humano e animal. O cenário de descaso obriga a população a comprar água para sobreviver, gastando o dinheiro que poderia ser destinado à comida.

Diariamente, nessas localidades, é possível ver dezenas de carroceiros vendendo água. Eles, que apuram até $\mathrm{R} \$ 40$ por dia, buscam o recurso nos chafarizes de Telha, comunidade situada a cerca de três quilômetros. A "carroçada d'água", como é chamada pelos moradores, custa $\mathrm{R} \$ 10$. São 400 litros, quatro tambores de cem.

O comércio d'água em Aquiraz é tão organizado que, em um dos chafarizes de Telha, das 6 às 11 horas, só os carroceiros podem usufruir do equipamento. Somente depois desse horário é que as outras pessoas podem se beneficiar. Outro, por exemplo, fica disponível para a população no período da manhã e, aos carroceiros, das14 às 18h. Cada um dos chafarizes possui uma espécie de "dono", que regula os horários de abastecimento.

"A água é regrada, não é toda hora que podemos pegar. Muitos clientes têm que pedir com dois dias de antecedência. A fila é grande, porque a maioria não tem como se descolar até os lugares que têm água", relata Francisco Severino da Silva, de 64 anos, que trabalha como carroceiro há mais de 15 anos. Francisco Severino sai de Água Verde, onde mora, até Telha quatro vezes por dia para buscar água. No vai e vem da carroça, puxada por um burro, apura $\mathrm{R} \$ 40$ por dia. 
A utilização de imagens e textos como estratégias de banalização e modos de naturalização das desigualdades em notícias sobre a pobreza dentro dos jornais

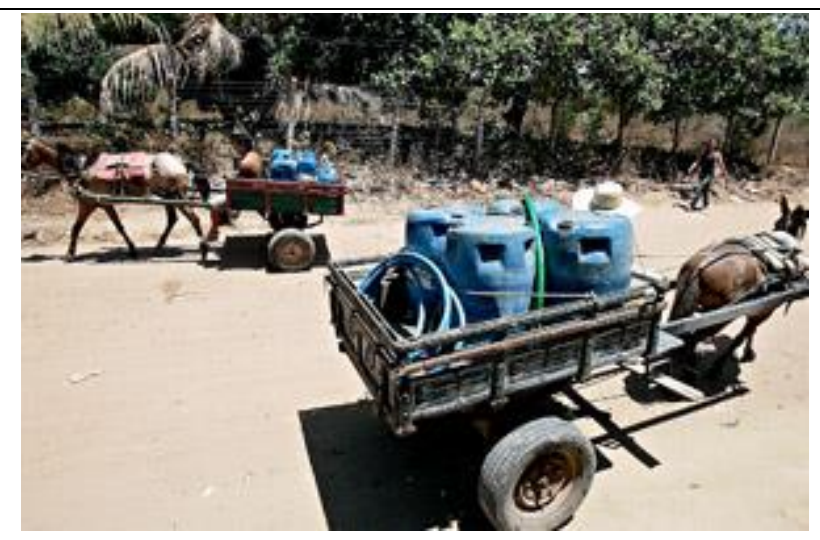

Imagem 2:

Todos os dias, carroceiros comercializam água encomendada por pessoas de duas comunidades de Aquiraz que dispõem apenas de água salobra. Foto: Kid Júnior.

Um de seus clientes é o comerciante José Abreu Maciel, 50. Pelo fato de possuir uma cacimba em sua residência, não comprava água com frequência. Mas, neste ano, devido à seca que atinge o Ceará, teve de optar pelas "carroçadas", já que as águas salgadas dos chafarizes de Área Verde "mata até sapo", como gosta de dizer quem vive naquela comunidade.

\section{Promessas}

"Á água só serve para lavar roupa", conta José Abreu Maciel, dizendo que a solução para o problema sempre é apresentada pelos candidatos a prefeito e vereador em período de eleição. Mas, quando estão no poder, de acordo com a população, os gestores públicos esquecem das promessas. "A gente fica esperando pela boa vontade deles, mas já estamos descrentes", reclama a dona de casa Leiliane Soares de Sousa, de 15 anos, informa que vive numa família de baixa renda. Porém, mesmo com as dificuldades financeiras, é preciso separar o dinheiro da água, que poderia ser de graça.

Moradores que não quiseram se identificar dizem que, muitas vezes, já foi pedida à atual e antigas gestões a compra de dessalinizadores. Eles denunciam que o abastecimento de qualidade não chega porque há interesses em manter esse comércio.

Em nota, a Companhia de Água e Esgoto do Ceará (Cagece) informa que a concessão do município detida pelo órgão diz respeito à zona urbana, sendo que essas comunidades citadas estão situadas em área rural. 


\begin{abstract}
A Companhia orienta que os moradores podem se organizar e pleitear para serem atendidos pelo Projeto São José, do Governo do Estado, que contempla as áreas rurais. Conforme a Cagece, a solicitação de estudo de viabilidade pode ser encaminhada por ofício até Superintendência de Obras Hidráulicas (Sohidra) ou a Cagece, em Aquiraz.

A reportagem tentou contato com a Prefeitura Municipal de Aquiraz para saber se existe projeto destinado a solucionar o impasse, mas, até o fechamento desta edição, ninguém atendeu aos telefonemas.
\end{abstract}

\title{
REPÓRTER: RAONE SARAIVA
}

Já de início, a notícia sobre as "carroçadas d'água" nos dá pistas para averiguarmos processos de eternalização do discurso: "O abastecimento precário nas comunidades de Área Verde e Camará, localizadas no município de Aquiraz, é tão antigo que os moradores já perderam a esperança de que um dia o problema será solucionado". Ora, se não há mais esperanças, então o discurso de que "vai ser sempre assim" é satisfatório. Como colocamos na seção 1, quando as pessoas tomam o que é dado como cultural, ele vira natural (Reificação) e passa a ser muito fácil dominar esses sujeitos. Se o problema da água em Aquiraz não tem mais jeito, reclamar pra que? O que a matéria do DN vai denunciar não é exatamente a carência da água, mas sim o comércio ilegal que se construiu em torno da falta desta.

Quando o redator coloca "Cada um dos chafarizes possui uma espécie de 'dono' que regula os horários de abastecimento" ele deixa sutilmente registrada sua crítica contra os carroceiros. Mas é preciso questionar também o porquê deste cartel ser tão bem sucedido e organizado e, mais ainda, porque um município tão próximo à região metropolitana de Fortaleza, com o favorecimento geográfico de estar vizinho a uma das maiores capitais do país poderia ser mais desenvolvido que muitos outros no interior do Estado, e vive nesta condição de penúria. Outro dado importante não mencionado na matéria é que em Aquiraz, o mesmo município que só dispõe de água salobra para uma parte de seus moradores, nós encontramos a menos de 10 quilômetros, na costa litorânea, um dos maiores complexos aquáticos da América Latina, o Beach Park, que conta com uma estrutura composta pelo parque aquático, quatro Resorts, além de restaurantes e serviços na praia paradisíaca do Porto das Dunas. A 
A utilização de imagens e textos como estratégias de banalização e modos de naturalização das desigualdades em notícias sobre a pobreza dentro dos jornais

500 metros de distância do Beach Park, também situado na praia do Porto das Dunas, o Oceani Beach Park Resort oferece aos visitantes mais 131 apartamentos e uma completa estrutura de lazer ${ }^{10}$.

O Beach Park tem essa imensa estrutura, que recebe diariamente dezenas de visitantes e turistas, e não utiliza "carros-pipa" (Carros utilizados para o abastecimento de água em regiões onde há escassez de recursos hídricos) para abastecer suas piscinas e sim dessalinizadores. Uma das nossas categorias de análise, a Desigualdade, fica estampada na constatação de que há vizinho a um resort tão bonito e cheio de água por todos os lados uma população em situação de pobreza comprando água salgada, que só serve para lavar roupa. (a matéria também "esqueceu” de informar como eles conseguem água para beber, pois tanto em Telha como em Água Verde, o consumo do que vem dos chafarizes é apenas para atividades domésticas). Há uma contradição enorme na situação exposta, apresentamos na seção 1 os direitos de um cidadão a ter acesso a coisas básicas como saúde, alimentação, moradia, mas aqui o que vemos é que falta algo bem mais básico que tudo isso: falta água.

NOTÍCIA 3 - OS INVISIVEIS DA BEIRA MAR

\section{Diário do Nordeste \\ Fortaleza, Ceará - Quarta-feira, 11de Julho de 2012 - Caderno}

Cidade, p.10.

\section{“MAIS DE 1/3 DOS MORADORES DE RUA NA CAPITAL VÊM DO INTERIOR"}

Durante o primeiro semestre desse ano, 13.056 usuários foram atendidos na Capital, uma média de 71 por dia.

A Capital é vista como um local de oportunidades, de futuro. Com essa e outras motivações, famílias sertanejas, a cada ano, fogem da seca e da fome para tentar a sorte em Fortaleza. Dados recentes da Secretaria Municipal de Assistência Social (Semas) revelam que dos 13.056 atendimentos realizados, entre janeiro e junho desse ano, no Centro de

${ }^{10}$ Fonte: http://www.beachpark.com.br/conheca-o-beach-park/estrutura acesso em 01 jul 2013, às 11h09min. 
Referência Especializado para Pessoas em Situação de Rua (CentroPop), $38 \%$, mais de um terço, são de pessoas do Interior do Ceará, ou seja, 3.573.

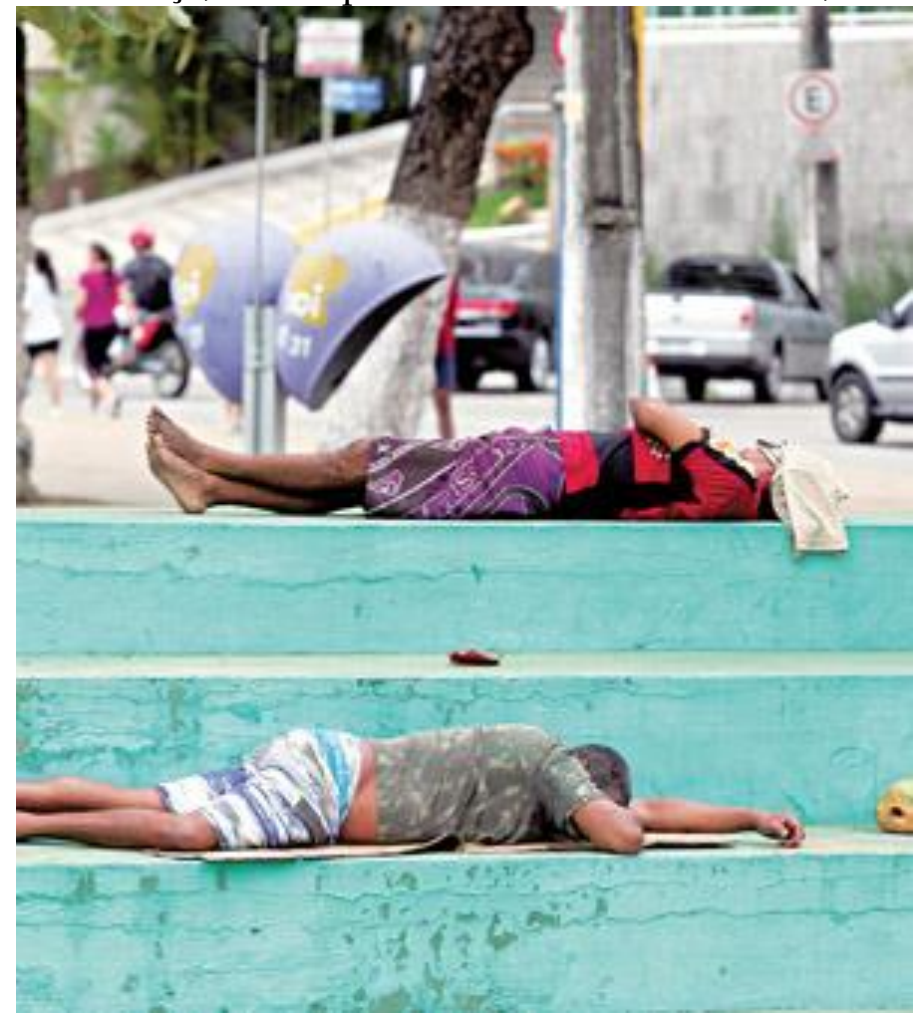

Imagem 3:

De acordo com a Semas, um dos principais locais de incidência de moradores de rua é a Beira-Mar, embora haja uma distribuição desta população Foto: José Leomar.

O abrigo atendeu uma média de 71 usuários a cada dia, todos com demandas bem variadas, que iam desde a solicitação de um lugar para a dormida, banho ou um prato de comida. E o movimento mensal foi crescente no CentroPop. Foram 2.060 demandas diretas em janeiro; 2.097, em fevereiro; 2.150, em março; 2.191, em abril e 2.257 e 2.301 nos dois períodos seguintes.

Há, segundo a coordenadora adjunta da Proteção Social Especial (PSE) da Semas, Gisele Machado, uma diversidade no perfil dos atendidos, mas essa grande demanda do Interior do Ceará chamou a atenção do grupo.

"Sabemos que a seca é fator importante de fuga para a cidade, mas ela não é a única. A Capital se torna atrativo e fica difícil a gente dar conta da demanda inteira de um Estado. Gestores têm que assumir sua parcela e 
A utilização de imagens e textos como estratégias de banalização e modos de naturalização das desigualdades em notícias sobre a pobreza dentro dos jornais

garantir políticas eficazes em todos os municípios", diz.

No fim do mês de maio, gestores públicos anunciaram a decretação de estado de emergência em 168 municípios cearenses, total de 91\% do território.

Além da origem dos que são recebidos no CentroPop, relatórios apontam outros dados que tentam "desenhar" a cara desse morador de rua que vive, hoje, nas praças e palafitas da Capital.

Entre os atendimentos realizados neste primeiro semestre, 83\% são de homens (10.829) e 17\% são mulheres (2.213). Com relação à geração de renda, $76 \%$ deles não trabalham (9.593) e $24 \%$ estão no mercado formal ou no informal (2.958). Sobre o nível de manutenção dos contatos com os familiares, $54 \%$ ainda possuem algum vínculo familiar, mesmo que fragilizado (6.791) e 46\% deles estão, sim, com os laços rompidos (5.561).

\section{Drogas}

Um dado entre tantos, chama a atenção: a predominância de moradores de rua que fazem o uso de álcool e outras drogas: 79\% deles dizem consumir alguma substância (9.945) e 21\% não fazem uso (2.500). Com relação a outras políticas públicas, $57 \%$ dos atendidos nunca acessaram (7.205) e 43\% já acessaram um dia os tais serviços (5.388).

Analisando o cenário apresentado, Gisele Machado comenta que, infelizmente, a situação desse público ainda é muito complicada, apesar dos avanços feitos, segundo ela, através das políticas de acesso à emprego, moradia e saúde. "O nosso desafio é fortalecer a autonomia deles, ajudá-los a conquistar alguns direitos e, assim, fazer com que sigam com as próprias pernas. O problema é que esses moradores estão sem autoestima, se sentindo derrotados e fragilizados", relata Gisele.

Mas onde habitam todos esses moradores de rua - muitas vezes invisibilizados pela população? Conforme a Semas, há, hoje, uma distribuição maior dessa população pela Capital.

Antes, a concentração se dava apenas na região central. Hoje, eles estão em diversos pontos, entre o Centro e bairros periféricos. O perfil da secretaria aponta os principais locais de incidência: Beira-Mar, Praia de Iracema e também no bairro do Benfica.

628 adultos conseguiram "dar a volta por cima" 
Em meio a tantas notícias negativas de moradores de rua sem emprego, renda, moradia, vivendo como "reféns" das drogas e da miséria, um dado positivo surge. De 2008 até hoje, um total de 628 adultos conseguiu superar a situação de vulnerabilidade extrema e "dar a volta por cima".

Acessaram, através de projetos sociais e também por vontade própria, diversos benefícios, como um emprego, alugar os próprios locais de residência, reatar laços familiares ou serem agraciados pelo aluguel social.

O cuidador de idosos André Luiz Jubilut, 58, ex-morador de rua, é um desses exemplos. Morou seis meses nas praças de Fortaleza por conta de dívidas e desajustes, diz ter sofrido muito. Mas, com apoio de "boas almas", conseguiu um emprego e, hoje, paga suas contas e o aluguel de R\$ 200 de um quarto no Centro.

"Qualquer lugar é melhor que a rua. Nossa, como eu sofri sem ter rumos nem sonhos. Para quem é morador de rua, uma ajuda qualquer já é muita coisa".

Para padre Lino Allegri, assessor da Pastoral do Povo da Rua, o momento é de apoio para essa população, de priorização e dedicação para que, com autonomia, consigam enfrentar seus problemas. "A gente até percebe que algo tem sido feito, mas ainda é pouco. Tem que se priorizar ainda mais o acesso à habitação, à saúde ao emprego. Essa população fragilizada não precisa só de caridade, mas, sim, de direitos".

\section{Serviços}

Através da Semas, a Prefeitura oferece à população de rua:

CentroPop (Centro de Referência Especializado para População em Situação de Rua); Espaço de Acolhimento Noturno; Serviço Especializado de Abordagem de Rua.

Ficam disponíveis, também, dois consultórios de rua, uma unidade móvel, atendimentos nos Centro de Atenção Psicossocial Álcool e Drogas (Caps-AD).

\section{REPÓRTER: IVNA GIRÃO}

Nesta notícia, podemos encontrar categorias importantes dentro do discurso, não só da repórter, mas também da sua entrevistada. A Desigualdade está dentro do texto, traiçoeiramente naturalizada. O 
A utilização de imagens e textos como estratégias de banalização e modos de naturalização das desigualdades em notícias sobre a pobreza dentro dos jornais

problema dos moradores de rua é visto como uma mancha que marca a bela Fortaleza, de praias lindas e povo caloroso. Quando se tenta retratar tal problema dentro da notícia, em momento nenhum há questionamento sobre o porquê da migração desestruturada do interior para os grandes centros urbanos acontecer. Ela apenas acontece, e a matéria já parte dessa premissa, não se discute a origem do fato, ele parece ser tratado como algo que está ali de forma atemporal. Podemos relembrar o conceito de Eternalização, modo de operação da ideologia que transforma os acontecimentos sociais e históricos em situações engessadas, sem esclarecimentos sobre seu começo ou fim. Ter moradores de rua é algo tão comum (outra estratégia ideológica aparece aqui, a Naturalização, um problema de cunho cultural torna-se comum, natural) que não se pergunta quando e como isso começou.

A entrevistada, coordenadora de um programa de proteção aos moradores de rua, tem em seu relato trechos muito relevantes que embasam nossa análise: “O nosso desafio é fortalecer a autonomia deles, ajudá-los a conquistar alguns direitos e, assim, fazer com que sigam com as próprias pernas. O problema é que esses moradores estão sem autoestima, se sentindo derrotados e fragilizados". Porque eles só têm possibilidades de conquistar alguns direitos? Porque não todos os que lhe são dados pela Constituição, como vimos na seção 1? Os moradores de rua também são considerados cidadãos pela justiça, mas como constatamos na análise da Carta Magna, falta muito para que se alcance esse status na prática, e o conceito de cidadania foge ao que é proposto em sua teoria. ${ }^{11}$ Muitos dos direitos ficam de fora quando analisamos a vida dos moradores de rua. Dentro do discurso do jornal constatamos que eles possuem demandas variadas, mas todas confrontam a falta de acesso às necessidades básicas: "as demandas iam desde a solicitação de um lugar para a dormida, banho ou um prato de comida".

Quando a entrevistada se refere a eles como pessoas que precisam de ajuda para conquistar "alguns" direitos, encontramos claramente um discurso

\footnotetext{
${ }^{11}$ No dicionário de Sociologia (1997, p.34), o verbete cidadão está correlacionado a três tipos distintos de direitos, especialmente em relação ao Estado. O cidadão deve ter acesso a 1. Direitos Civis, que incluem direito a livre expressão, informação sobre os acontecimentos, reunião, locomoção e organização sem restrição indevida. 2) Direitos Políticos, que incluem o direito de votar e 3. Direitos Socioeconômicos, que incluem o direito ao bem-estar e à segurança social.
} 


\section{Bruna Clézia Madeira Neri \\ Francisca Denise Silva do Nascimento}

que alimenta a Exclusão. Na tentativa de dar-lhes "autonomia", percebemos o que Sawaia (2010) aponta como uma inclusão perversa. A tentativa fracassada de inclusão com o "apoio de boas almas" torna o problema ainda pior, pois eles passam a ser dependentes de alugueis sociais ou simplesmente não aceitam as possibilidades que lhes são dadas (porque muitas vezes simplesmente dão a chance de eles terem uma vida melhor, mas não se explica como eles utilizarão essa oportunidade), voltando para a rua por conta própria.

Outra consequência que aparece no relato é o uso de drogas. Os números e porcentagens de usuários ficam soltos, e se subentende que além de vagabundos, eles também são drogados. Recorrer a entorpecentes, entretanto, nem sempre é uma escolha. Não se pontua na notícia que a fome e o frio são situações cruéis e que ao se drogarem, essas pessoas conseguem se desligar por algum tempo da triste realidade em que vivem. Muitas drogas aliviam a sensação de fome e isso ajuda a suportar o sofrimento. Castel (2010) defende que ao lado da indigência estrutural, uma massa importante de pessoas vive em condição precária e basta uma situação conjuntural para que caiam na dependência. $\mathrm{O}$ uso contínuo, obviamente, leva ao vício e a essa dependência, e sim, com certeza esses números além de altos tem uma forte possibilidade de crescerem a cada dia, pois a droga é uma das saídas mais rápidas e viáveis que os moradores aceitam.

É irônico perceber que os moradores de rua da matéria estão, entre outros lugares, na Beira-Mar, a avenida mais bonita e luxuosa da capital, um dos cartões postais do Ceará. Nessa mesma avenida acontecem com frequência shows com megaestruturas, patrocinados pela prefeitura e é também lá que estão os hotéis mais caros do Estado. O investimento turístico nessa área nobre de Fortaleza é maciço, mas não consegue conter a leva de "vagabundos indigentes" (CASTEL, 2010), que se alojam nos bancos do calçadão onde pessoas passam diariamente caminhando, passeando ou correndo - é inegável a desigualdade presente nesse espaço, mas a notícia não pode? Deve? Quer? Repassar isso. Ficam o dia todo transitando de um lado para o outro, alguns vendendo bugigangas, com pouca ou talvez nenhuma perspectiva de que algo mude, mas a notícia aponta que eles podem, se quiserem, ter acesso a alguns direitos. Quem sabe um dia alcancem o direito de serem vistos. 
A utilização de imagens e textos como estratégias de banalização e modos de naturalização das desigualdades em notícias sobre a pobreza dentro dos jornais

\section{Conclusão}

Dentro das investigações no estudo das práticas de naturalização e banalização da desigualdade, nos deparamos por diversas vezes com notícias que realçavam mais a miséria humana em si do que a própria história a ser narrada, fosse ela um crime, uma denúncia ou um mero observar do cotidiano dos sujeitos. O estar desigual e inferiorizado é uma condição cruel, e fica mais nítida ainda quando se coloca no papel, de uma forma distorcida e, em muitos casos, não contada, o relato de sofrimentos diários que indivíduos neste patamar enfrentam e que nem sempre tem voz.

Há um preço muito alto a ser pago por estarmos inseridos dentro de uma engrenagem capitalista que simplesmente não para $e$, de forma avassaladora, vai esmagando mais e mais pessoas "invisíveis" a cada momento. Há mais de cem anos, Karl Marx já apontava os efeitos apocalípticos do desenfreado sistema que estava se erguendo diante dos olhos de todos, como um gigante que desperta e pisoteia tudo a sua volta. Mal sabia o sonhador filósofo alemão que graças a seus alertas, aqueles que estavam no poder, a classe especializada criticada por Chomsky (que mesmo cruel é também muito ardilosa e inteligente) iria perceber o erro cometido e consertá-lo e, aqui estamos nós, vivendo sob os mesmo ditames de antes, com regras diferentes, mas seguindo o mesmo rumo.

O que faz um país ter tantos pobres? A burocracia nos impede de descobrirmos muita coisa sobre esse questionamento, mas ainda assim, ela é um caminho para atravessarmos o outro lado da pergunta. Entretanto, sempre haverá respostas mais rápidas e simples, dadas por outros depósitos de saber, e um deles foi tema deste trabalho: a mídia. É ela uma das mais convincentes fontes de respostas para tudo o que precisamos saber, ter, comprar e acreditar (dentre outros diversos "benefícios"). É através da mídia que significamos boa parte dos recados dados desde a tenra infância, a respeito do que devemos gostar de usar, o que é adequado assistir e o que é certo defender. Quando trabalhamos com o jornal, um meio de comunicação e informação tão antigo e ao mesmo tempo, tão atual, ficamos cara a cara com o seu objetivo primário: transmitir os fatos.

Porém, é tão comum saber para quê o jornal serve que não há motivos para nos questionarmos sobre isso, já que desde sempre ele fez o que faz hoje, repassar as notícias. O servir, entretanto, sempre aponta para dois 


\section{Bruna Clézia Madeira Neri \\ Francisca Denise Silva do Nascimento}

caminhos. Há uma subserviência e um uso embutidos dentro da palavra. O jornal serve para dar notícia, mas a quem ele serve quando cumpre sua tarefa? $\mathrm{Na}$ tentativa de juntar explicações viáveis para responder de forma adequada a esta pergunta, me fiz outra: será que o jornal serve unicamente para transmitir o que acontece, ou há algo mais que vem junto com os fatos "limpos e secos"? Defendi até aqui que sim, há algo além. Quando o jornal trabalha com temas envolvendo a pobreza, ele traz dentro de seu conjunto de cadernos, imagens, anúncios, e manchetes também discursos que legitimam práticas de naturalização e banalização desses temas.

Ao longo de toda a discussão, teci argumentos versando sobre poder maléfico de tais práticas para a sociedade. Apoiei-me para isso no conceito de Ideologia, como forma de justificar a utilização de estratégias de dominação e poder. Na investigação, foi ressaltada a importância da ideologia dentro da mídia, como um alicerce na disseminação de conceitos sobre o que é a pobreza, e o resultado disso, uma situação de exclusão a nível global.

Por fim, para sustentar meus achados teóricos, analisei quatro notícias de jornal enfocando a argumentação na baia da Análise Crítica do Discurso, metodologia de extremo respaldo quando se faz necessário investigar as construções multimodais da linguagem, seja ela escrita ou falada. Mais que folhas inúteis ao findar o dia, os jornais tem seu devido uso e importância quando nos atravessam ao transmitirem os acontecimentos que geralmente não pudemos presenciar. O ápice de um jornalismo crítico, com qualidade e respaldo, é ser capaz de fazer essa transmissão de maneira ética, guiada por princípios que estejam regrados na compreensão de que, sejam nas favelas, praças abandonadas ou grandes centros urbanos, o foco de uma notícia bem elaborada deve residir, a nosso ver, na sua capacidade de expor o outro com humanidade e respeito.

Referências

BAUER, Martin W.; GASKELL, George et al.Pesquisa Qualitativa com Texto, Imagem e Som: Um manual prático. Petrópolis, RJ: Vozes, 2002. BAUER, M. W; AARTS, B. A construção do corpus: um princípio para a coleta de dados quantitativos. In BAUER, Martin W.; GASKELL, George et al.Pesquisa Qualitativa com Texto, Imagem e Som: Um manual prático. Petrópolis, RJ: Vozes, 2002. 
A utilização de imagens e textos como estratégias de banalização e modos de naturalização das desigualdades em notícias sobre a pobreza dentro dos jornais

BEGHIN, N. Notas sobre desigualdade e pobreza no Brasil: situação atual e desafios. In GREEN, Duncan. Da Pobreza ao Poder. São Paulo: Cortez, 2009.

BRASIL. Constituição (1988). Constituição da República Federativa do

Brasil: promulgada em 5 de outubro de 1988, atualizada até a Emenda Constitucional no 39, de 19 de dezembro de 2002. 31 ed. São Paulo: Saraiva, 2003.

CARVALHO, Rodrigo. Decon multa CAGECE por falta de abastecimento. Diário do Nordeste, Fortaleza, 3 outubro 2012. Cidade, p.4.

CASTEL, Robert. As Metamorfoses da Questão Social: Uma crônica do salário. 9 ed. Petrópolis, RJ: Vozes, 2010.

DIJK, Teun A. van. Discurso e Poder. 2 ed. São Paulo: Contexto, 2012. DORNELES, Carlos. Deus é Inocente: A imprensa, não. São Paulo: Globo, 2003.

ESPÍNOLA, G.M; SANTOS, M.S; ANDRADE, M.A. A incidência da pobreza no Brasil: uma análise empírica, 1992-2005. In CONFERÊNCIA NACIONAL DE POLÍTICAS PÚBLICAS CONTRA A POBREZA E A DESIGUALDADE, 1. 2010, Natal. Anais...Natal: UFRN, 2006. Disponível em $<$ http://www.cchla.ufrn.br/cnpp/pgs/anais/anais.html $>$. Acesso em: 24 jun. 2013.

GABRIEL, Mary. Amor e Capital: A saga familiar de Karl Marx e a história de uma revolução. Rio de Janeiro: Zahar, 2013.

GIL, R. Análise de Discurso. In BAUER, Martin W.; GASKELL, George et al.Pesquisa Qualitativa com Texto, Imagem e Som: Um manual prático.

Petrópolis, RJ: Vozes, 2002.

GIRÃO, I. Mais de 1/3 dos moradores de rua na capital vêm do interior.

Diário do Nordeste, Fortaleza, 11 de julho 2012. Cidade, p.10.

GREEN, Duncan. Da Pobreza ao Poder. São Paulo: Cortez, 2009.

GUARESCHI, Pedrinho A. et al. Os Construtores da Informação: Meios de Comunicação, ideologia e ética. Petrópolis, RJ: Vozes, 2000.

Pedrinho A. Psicologia Social Crítica: Como prática de

libertação. 5 ed. Porto Alegre: EDIPUCRS, 2012.

Pedrinho A. Sociologia da Prática Social. 3 ed. Petrópolis, RJ:

Vozes, 1992b.

Pedrinho A.; BIZ, Osvaldo. Mídia, Educação e Cidadania:

Tudo o que você deve saber sobre a mídia. 2 ed. Petrópolis, RJ: Vozes, 2005. 
Bruna Clézia Madeira Neri

Francisca Denise Silva do Nascimento

Brasília, v.12, n.3-4, 1992a.

P. A. Pressupostos Psicossociais da Exclusão:

Competitividade e Culpabilização. In Sawaia, B. (Org.). As Artimanhas da Exclusão: Análise psicossocial e ética da desigualdade social. 10 ed.

Petrópolis, RJ: Vozes, 2010.

JOHNSON, Allan G. Dicionário de Sociologia: um guia prático da

linguagem sociológica. Rio de Janeiro: Zahar, 1997.

LÖWY, Michael. Ideologias e Ciência Social: Elementos para uma análise marxista. 2 ed. São Paulo: Cortez, 1986.

MÉSZÁROS, István. O Poder da Ideologia. São Paulo: Boitempo, 2012.

NASCIMENTO, E. P. de. Hipóteses sobre a Nova Exclusão Social: dos

excluídos necessários aos excluídos desnecessário. Cad. CRH, Salvador, v. 7, n.21, p.29-47, jul/dez. 1994.

NOAM, Chomsky. Controle da mídia: os espetaculares feitos da propaganda. Rio de Janeiro: Graphia, 2003.

PAULA, F. de. Trato com moradores de rua gera preocupação. Diário do Nordeste, Fortaleza, 14 de dezembro 2012. Cidade, p.8.

QUINTANEIRO, Tânia. (Org.) Um toque de clássicos: Marx, Durkheim e Weber. 2 ed. Belo Horizonte: Editora UFMG, 2002.

REIGOTA, M. Quem lê tanta notícia? O meio ambiente na imprensa de Sorocaba, Florianópolis e Macapá. In SPINK, Mary Jane; SPINK, Peter.

(Org.). Práticas Cotidianas e a Naturalização da Desigualdade: Uma semana de notícias nos jornais. São Paulo: Cortez, 2006.

SAWAIA, Bader. (Org.) As Artimanhas da Exclusão: Análise psicossocial e ética da desigualdade social. 10 ed. Petrópolis, RJ: Vozes, 2010.

B. Identidade - Uma ideologia separatista? In Sawaia, B. (Org.).

As Artimanhas da Exclusão: Análise psicossocial e ética da desigualdade social. 10 ed. Petrópolis, RJ: Vozes, 2010.

SILVA, Marconi Oliveira da.Era Tudo Mentira: A Verdade Jornalística. São Paulo: Intermeios, 2011.

SPINK, Mary Jane; SPINK, Peter.(Org.). Práticas Cotidianas e a

Naturalização da Desigualdade: Uma semana de notícias nos jornais. São

Paulo: Cortez, 2006.

P. A Desigualdade Cotidiana - a naturalização de materialidades

territoriais. In SPINK, Mary Jane; SPINK, Peter. (Org.). Práticas Cotidianas

Latitude, Vol. 10, no 1, pp. 50-82, 2016 
A utilização de imagens e textos como estratégias de banalização e modos de naturalização das desigualdades em notícias sobre a pobreza dentro dos jornais

e a Naturalização da Desigualdade: Uma semana de notícias nos jornais. São Paulo: Cortez, 2006.

M. J. O poder das imagens na naturalização das desigualdades: os crimes no cotidiano da mídia jornalística. In SPINK, Mary Jane; SPINK, Peter. (Org.). Práticas Cotidianas e a Naturalização da Desigualdade: Uma semana de notícias nos jornais.São Paulo: Cortez, 2006.

THOMPSON, John B. A Mídia e a Modernidade: Uma teoria social da mídia. 13 ed. Petrópolis, RJ: Vozes, 2012.

JOHN, B. Ideologia e Cultura Moderna: Teoria social crítica na era dos meios de comunicação de massa. 9 ed. Petrópolis, RJ: Vozes, 2011.

VOLLMANN, William T. Por que vocês são pobres? São Paulo: Conrad Editora do Brasil, 2010.

SARAIVA,Raone. População da zona rural compra água para sobreviver. Diário do Nordeste, Fortaleza, 18 outubro 2012. Cidade, p.6. Raone. Praças sofrem com abandono e vandalismo. Diário do Nordeste, Fortaleza, 16 outubro 2012. Cidade, p.6.

WANDERLEY, M. B. Refletindo sobre a noção de exclusão. In Sawaia, B. (Org.). As Artimanhas da Exclusão: Análise psicossocial e ética da desigualdade social. 10 ed. Petrópolis, RJ: Vozes, 2010.

REY, F.L. G. A violência: gênese, manipulação e ocultamento social. In Sawaia, B. (Org.). As Artimanhas da Exclusão: Análise psicossocial e ética da desigualdade social. 10 ed. Petrópolis, RJ: Vozes, 2010.

Enviado em: 29/02/2016

Aceito em: 28/07/2016 